\title{
ARTIGO - PRÁTICAS DE ENSINO DA LEITURA E DA ESCRITA NA EDUCACC̃̃O INFANTIL NO BRASIL E NA FRANCA E OS CONHECIMENTOS DAS CRIANC̦AS SOBRE A ESCRITA ALFABÉTICA ${ }^{1}$
}

ELIANA BORGES C. DE ALBUQUERQUE' ORCID: https://orcid.org/0000-0002-7162-8466

ANDREA TEREZA BRITO FERREIRA'

ORCID: https://orcid.org/0000-0003-1711-2327

'Universidade Federal de Pernambuco, Programa de Pós-Graduação em Educação, Recife, PE, Brasil.

Eliana B. C. de Albuquerque - Doutora em Educação pela Universidade Federal de Minas Gerais (UFMG). Professora do Programa de Pós-Graduação em Educação da UFPE.

E-mail:<eliana.balbuquerque@gmail.com>.

Andrea T. B. Ferreira - Doutora em Sociologia pela Universidade Federal de Pernambuco (UFPE). Professora do Programa de Pós-Graduação em Educação da UFPE. E-mail:< andreatbrito@gmail.com> .

RESUMO: $\mathrm{O}$ estudo analisou práticas de ensino da leitura e da escrita em duas turmas do último ano da Educação Infantil: uma pertencente à rede pública de ensino da cidade do Recife/PE (Brasil) e outra localizada em Paris (França). Buscou-se analisar mais especificamente o trabalho voltado para a apropriação da escrita alfabética a partir das atividades de leitura e escrita desenvolvidas em sala de aula. Como procedimentos metodológicos, foram realizadas observações do cotidiano escolar, entrevistas com as duas professoras e atividades de escrita de palavras com os alunos. A análise dos dados indicou que as docentes organizavam o seu trabalho pedagógico de modo a privilegiar a leitura e exploração de textos que faziam parte do universo infantil, e o desenvolvimento de atividades diversificadas e lúdicas que levavam os alunos a refletirem sobre os princípios da escrita alfabética. Quanto aos conhecimentos das crianças sobre a escrita alfabética, a maioria dos alunos das duas turmas concluiu o ano estabelecendo relações entre a escrita e a pauta sonora das palavras.

Palavras-chave: Educação Infantil. Alfabetização. Leitura e escrita. Práticas de ensino.

TEACHING PRACTICES OF READING AND WRITING IN EARLY CHILDHOOD EDUCATION IN BRAZIL AND FRANCE AND CHILDREN'S KNOWLEDGE OF ALPHABETIC WRITING

ABSTRACT: This study investigated the reading and writing teaching practices in two pre-school classes (five-year-old children): one belonging to the 
public schools in Recife/PE (Brazil) and another in Paris (France). It was sought to analyze more specifically the work focused on the appropriation of alphabetic writing from the reading and writing activities developed in the classroom. The methodological procedures were interviews, observations of the daily school routine, and writing words activities with students. The analysis of the collected data showed that the teachers organized their pedagogical work in order to emphasize the use of texts and readings that were already part of the children's universe, and also developed games and activities that led the students to think about the principles of alphabetic writing. At the end of the school year most students of both classes showed understanding of the relationship between writing and the sound of words. Keywords: Early childhood education. Literacy. Reading and writing. Teaching practices.

\section{INTRODUÇÃO}

No Brasil, a ampliação do Ensino Fundamental para nove anos (Lei $\mathrm{n}^{\circ} 11.274$, de 6 de fevereiro de 2006) provocou um intenso debate sobre o que fazer com as crianças de seis anos - que não mais frequentariam a Educação Infantil -, no que se refere ao ensino da leitura e da escrita. Muitos temiam uma antecipação da alfabetização relacionada a práticas correntes que priorizavam a memorização e escrita de letras, sîlabas e palavras. Para outros, a alfabetização nessa perspectiva não deveria mais ocorrer nem com alunos de seis anos, recém ingressos no Ensino Fundamental, nem com os de sete (que frequentavam a antiga $1^{\mathrm{a}}$ série), nem mesmo com os da Educação de Jovens e Adultos.

Em 2014, o Plano Nacional de Educação (PNE), aprovado pela Lei $\mathrm{n}^{\mathrm{o}} 13.005$, de 25 de junho do referido ano, estabeleceu, como Meta 1, a universalização, até 2016, da educação infantil na pré-escola para as crianças de 4 (quatro) a 5 (cinco) anos de idade. A Meta 5, por sua vez, era a de "alfabetizar todas as crianças, no máximo, até o final do 3 (terceiro) ano do ensino fundamental", correspondente ao último ano do Ciclo da Alfabetização que passou a envolver os três primeiros anos do Ensino Fundamental.

Com a homologação, em 20 de dezembro de 2017, da Base Nacional Comum Curricular (BNCC), direitos e objetivos de aprendizagem e desenvolvimento são propostos para as diferentes etapas e modalidades da Educação Básica, incluindo a Educação Infantil. Com a publicação do referido documento, outras - ou as mesmas - questões são intensificadas: $\mathrm{O}$ que que fazer com as crianças de 4 e 5 anos em relação ao trabalho com a língua escrita? Quando e como alfabetizar nossos alunos? Qual o momento de iniciar esse processo? 
As respostas a tais questões podem ser encontradas no decreto $\mathrm{n}^{\circ}$ 9.765, publicado no dia 11 de abril de 2019, que instituiu a Política Nacional de Alfabetização (PNA) como uma das metas do Ministério da Educação para os 100 primeiros dias do governo do Presidente Jair Bolsonaro. Tomando como referência o relatório final "Alfabetização Infantil: os novos caminhos", elaborado a pedido da Comissão de Educação e Cultura da Câmara dos Deputados, o PNA tem, como um dos seus princípios, "a ênfase no ensino dos seis componentes essenciais para a alfabetização: consciência fonêmica, instrução fônica sistemática, fluência em leitura oral, desenvolvimento de vocabulário, compreensão de textos e produção escrita". Em relação à Educação Infantil, entre suas diretrizes, o PNA ressalta a importância do desenvolvimento da linguagem oral e de habilidades fundamentais para a alfabetização na educação infantil, o que parece propor que essa etapa da educação básica seja uma preparação para a entrada no Ensino Fundamental, mais especificamente para o ciclo de alfabetização que, a partir da BNCC, passou a envolver os dois primeiros anos do Ensino Fundamental.

Em relação ao contexto francês, até 2014 o ciclo de alfabetização envolvia o último ano da Educação Infantil e os dois primeiros anos do Ensino Fundamental. Como abordado por Chartier (2007), no último ano da Educação Infantil (primeiro ano do ciclo de alfabetização) as crianças deviam ter a oportunidade de fazer numerosas descobertas sobre a existência do código escrito, seu funcionamento, suas regras de correspondência, cabendo à turma de alfabetização (CP) o ensino mais sistemático do código alfabético, com base nos conhecimentos que os alunos já teriam construídos.

Em 2015 houve uma mudança na organização dos ciclos no sistema francês. O Ciclo 1 passou a envolver os três anos da Educação Infantil ${ }^{2}$ e o ciclo 2, "ciclo das aprendizagens fundamentais", engloba os três primeiros anos do Ensino Fundamental (CP, CE1 e CE2). O Programa de ensino francês relativo ao ciclo das aprendizagens fundamentais (Ciclo 2), publicado no Boletim Oficial especial $\mathrm{n}^{\circ}$ 11 de 26 de novembro de 2015, explicita que, no referido ciclo, a língua francesa constitui o objeto de aprendizagem central, e deve envolver a oralidade, a leitura e a escrita. O documento faz referência às competências desenvolvidas na Educação Infantil, relacionadas, entre outras coisas, à descoberta do princípio alfabético.

Observa-se, portanto, que na França as orientações oficiais para o trabalho com a linguagem na Educação Infantil envolvem, há alguns anos, o trabalho de compreensão do funcionamento da escrita 
alfabética por meio de diferentes atividades de exploração dos estratos sonoros da fala e sua relação com a escrita. No Brasil, documentos como os Parâmetros Curriculares Nacionais para a Educação Infantil e a BNCC não tratam especificamente do trabalho com a apropriação da escrita alfabética na Educação Infantil. A leitura e a escrita são, nesses documentos, inseridas em um contexto mais amplo, no qual se integram diferentes habilidades relacionadas à linguagem.

Em 2019, temos assistido, no Brasil, a uma virada no tratamento da linguagem na escola a partir do PNA, que põe ênfase na alfabetização vinculada ao método fônico e no ensino explícito das correspondências entre fonemas e grafemas. Nesse contexto, ressaltamos a importância de se discutir como o trabalho de apropriação da escrita alfabética pode ser vivenciado na Educação Infantil com base no respeito à subjetividade e interesses das crianças dessa etapa da escolarização, com ênfase em atividades lúdicas e que possibilitem que elas vivenciem a cultura escrita de forma a ampliar suas experiências de vida, considerando as práticas sociais de leitura e escrita, o letramento.

Nesse artigo, apresentaremos dados de uma pesquisa que buscou analisar as práticas de ensino da leitura e da escrita em duas turmas do último ano da Educação Infantil - uma no Brasil e outra na França - e os conhecimentos dos alunos em relação à escrita alfabética.

\section{O ENSINO DA LEITURA E DA ESCRITA: COMO E QUANDO ALFABETIZAR AS CRIANÇAS?}

Quando falamos em alfabetizar crianças no Brasil, podemos nos referir a variadas práticas de ensino da leitura e da escrita, desde aquelas vinculadas ao ensino de letras, fonemas, sílabas e palavras com base em textos cartilhados, como o que propõem diferentes métodos de alfabetização (métodos silábicos e fônicos, por exemplo), até a inserção nas práticas sociais de leitura e escrita. Da mesma forma, podemos nos referir a práticas desenvolvidas desde a Educação Infantil e que engloba todo o período de escolarização dos alunos, ou mais especificamente àquelas vinculadas ao ensino formal e sistemático da leitura e da escrita realizado em turmas de alfabetização (crianças de 6-7 anos de idade), ou no $1^{\circ}$ ciclo do Ensino Fundamental. As diferentes práticas de alfabetização relacionam-se a mudanças de naturezas didática e pedagógica no ensino da leitura e da escrita, decorrentes de diferentes aspectos - desenvolvimento científico em diferentes áreas, contexto socioeconômico, organização escolar etc. 
A concepção de alfabetização como o ensino das habilidades de codificação e decodificação, predominante durante o século XX, foi pedagogicamente efetivada por meio da criação de diferentes métodos de alfabetização - métodos sintéticos (fônicos e silábicos, por exemplo) $\mathrm{x}$ métodos analíticos (método global, por exemplo) - que padronizaram a aprendizagem da leitura e da escrita. As cartilhas relacionadas a esses métodos passaram a ser amplamente utilizadas como livro didático para o ensino nessa área e se constituíam, na maioria das vezes, no único ou no principal material de ensino da leitura e da escrita.

Ensinar a ler e escrever com base nos métodos analíticos ou sintéticos exigia que as crianças apresentassem uma prontidão para o início do processo de alfabetização. Essa prontidão estava relacionada ao desenvolvimento de habilidades perceptivas e motoras e, na maioria das vezes, era desenvolvida na Educação Infantil. Assim, o trabalho com a linguagem nessa primeira etapa da escolarização era repleto de atividades que levavam as crianças a desenvolver habilidades de coordenação motora e discriminação auditiva e visual, e essas atividades envolviam, entre outras, a identificação e o traçado de letras e sílabas isoladas. Nesse contexto, a leitura e a escrita eram evitadas, e o acesso aos textos limitava-se, muitas vezes, à prática de contar histórias realizada pela professora, como forma de tornar o texto escrito mais simples e, consequentemente, mais "fácil" de ser compreendido.

$\mathrm{Na}$ década de 1980, os trabalhos de Emília Ferreiro e Ana Teberosky sobre a Psicogênese da Lingua Escrita (FERREIRO \& TEBEROSKY, 1984) vão abrir uma nova possibilidade de desenvolvimento das práticas de alfabetização no Brasil. Criticando a concepção de língua escrita como código, o qual se aprenderia a partir de atividades de memorização das correspondências entre fonemas e grafemas, as autoras defenderam uma concepção de língua escrita como um sistema de notação que, no nosso caso, é alfabético. Segundo as referidas autoras, no processo de apropriação do sistema de escrita alfabética, as crianças (ou adultos) em processo de alfabetização precisam compreender como esse sistema funciona e, para isto, necessitam perceber o que a escrita nota (ou "representa", "grafa") e como a escrita cria estas notações (ou "representações"). Precisam, portanto, entender que o que a escrita alfabética nota no papel são os sons das partes orais das palavras e que essa notação é feita considerando-se os segmentos sonoros menores que a sílaba (os fonemas). Até atingirem esse nível de compreensão, que caracteriza a escrita alfabética, as autoras constataram que as crianças ou adultos analfabetos passavam por outras fases: escrita pré-silábica, em que não 
há correspondência grafofônica e escrita silábica, em que já há essa correspondência mas no nível da sílaba (uma letra representaria um sílaba) e não do fonema.

A difusão dos trabalhos da Psicogênese da Lingua Escrita no Brasil aconteceu paralelamente ao fortalecimento de um discurso contrário ao uso dos tradicionais métodos de alfabetização. Pregavase a necessidade de possibilitar que as crianças se apropriassem do sistema de escrita alfabética a partir da interação com diferentes textos escritos, por meio de atividades significativas de leitura e produção de textos, desde a Educação Infantil. Na década de 1990, um novo conceito de alfabetização relacionado às práticas de leitura e escrita passou a ser difundido no Brasil: o de letramento. Segundo Soares (1998), o termo letramento é a versão para o Português da palavra de língua inglesa literacy, que significa o estado ou condição que assume aquele que aprende a ler e escrever.

Diante das mudanças teóricas na área de alfabetização, decorrentes principalmente dos estudos sobre a psicogênese da língua escrita e sobre as práticas de letramento, a discussão acerca de como e quando alfabetizar nossos alunos têm se intensificado e revelam perspectivas diferenciadas no trabalho com a língua escrita na Educação Infantil e nos anos iniciais do Ensino Fundamental.

Brandão e Leal (2011) apontam três caminhos para o trabalho com a linguagem na Educação Infantil. O primeiro, denominado por elas de "A obrigação da alfabetização", considera que os anos que antecedem o Ensino Fundamental devem preparar o aluno para a alfabetização e, para isso, a ênfase está no desenvolvimento de habilidades perceptuais e motoras. Espera-se que os alunos concluam a Educação Infantil "dominando certas associações grafofônicas, copiando letras, palavras e pequenos textos, bem como lendo e escrevendo algumas palavras e frases" (p. 16) para, no primeiro ano, iniciarem o processo de alfabetização propriamente dito com base em métodos sintéticos ou analíticos de ensino da leitura e da escrita. O segundo caminho - "O letramento sem letras" -, ao contrário do primeiro, propõe que o trabalho na Educação Infantil envolva outros tipos de linguagem (a corporal, a musical, a gráfica, entre outras), não havendo espaço para o trabalho com a linguagem escrita, uma vez que se deseja banir qualquer trabalho que envolva a escrita como "conteúdo escolar", nos moldes do que era desenvolvido no Caminho 1. O Terceiro caminho negaria os dois anteriores ao propor um trabalho com a língua escrita na Educação Infantil que envolva, por um lado, atividades que levem as crianças a se apropriarem do sistema 
de escrita alfabética por meio de atividades lúdicas e reflexivas e, por outro, situações diversificadas de leitura e escrita de modo a garantir a ampliação de suas experiências de letramento.

$\mathrm{Na}$ França, como apontado por Chartier (2016), o método silábico de alfabetização, majoritário desde o início do século XX e sempre presente nos manuais de sucesso das editoras de livros escolares, parecia, nos anos 1970-80, arcaico por favorecer uma leitura mecânica e sem compreensão, centrada na oralização das palavras pela decifração das sílabas. Assim, com o objetivo de levar os alunos a se interessarem de imediato pelo sentido dos textos, uma entrada pela leitura global passou a ser considerada, pois o reconhecimento das palavras inteiras poderia acelerar a compreensão das frases. "A prioridade era conseguir que todos chegassem à leitura funcional (functional literacy), necessária em uma sociedade invadida por escritas utilitárias" (p. 286), de modo a se enfrentar o fenômeno do "iletrismo".

Enquanto todo mundo pensava que o nível de alfabetização de uma sociedade bem escolarizada era irreversível, descobria-se que os procedimentos construídos para ensinar a ler não tornavam as pessoas capazes de "ler tudo", já que as mudanças dos fins sociais da leitura tinham feito surgir ao mesmo tempo o fracasso escolar de massa e o fenômeno moderno do iletrismo (CHARTIER, 2016, p. 216)

Diferentemente do que aconteceu no Brasil, em que a discussão sobre letramento de certa forma levou a um apagamento da especificidade do processo de alfabetização (SOARES, 2003), na França tal discussão se relacionou ao fenômeno do iletrismo dos adultos e na legitimação de um novo objetivo escolar: preparar os alunos para os usos funcionais da leitura, preservando-os do fracasso escolar (CHARTIER, 2016).

Em relação à influência da psicogênese da escrita nas práticas de alfabetização em escolas da França, Chartier (2010) aponta que os saberes científicos da referida teoria, muito difundidos no Brasil principalmente no que se refere à identificação das hipóteses de escrita das crianças, não têm sido utilizados pelos professores franceses, que prescindem daquelas categorias de análise sem que os resultados de seus alunos e sua prática pedagógica pareçam ser afetados. Segundo a referida autora, apesar de desconhecerem o processo de apropriação da escrita como apontado por Ferreiro e Teberosky, os docentes realizam um trabalho, na Educação Infantil, de modo a garantir que as crianças, ao iniciarem a classe de alfabetização (CP), compreendam o funcionamento da escrita alfabética. Nesse sentido, no final da Educação Infantil, os alunos franceses possuem saberes sobre as línguas oral e escrita, em geral, bem mais avançados que 
no Brasil, uma vez que elas vivenciam atividades diferenciadas que envolvem, por exemplo, a exploração dos nomes dos alunos e os jogos fonológicos (como aqueles de "caça aos sons parecidos"), que ajudam a progredir em direção a uma etapa posterior.

A pesquisa desenvolvida por Coutinho-Monnier (2009) com turmas do $1^{\circ}$ ano do Ensino Fundamental em escolas do Brasil e da França ressalta as diferenças existentes entre os saberes das crianças brasileiras (de escolas públicas) e francesas em relação à escrita ao concluírem a Educação Infantil. A referida pesquisadora percebeu que os alunos das duas turmas do CP da França por ela investigadas iniciaram o ano letivo com hipóteses silábico-alfabéticas ou alfabéticas de escrita, o que não aconteceu com a maioria dos alunos das seis turmas do $1^{\circ}$ ano do Brasil que participaram da pesquisa.

Como já apontado anteriormente, as orientações oficiais francesas em relação à Educação Infantil explicitam a importância do desenvolvimento de atividades fonológicas que levem as crianças a compreenderem o funcionamento da escrita alfabética. Na seção a seguir, abordaremos como as propostas curriculares do Brasil e da França têm tratado a questão do trabalho com a linguagem escrita na Educação Infantil.

\section{O QUE DIZEM OS TEXTOS OFICIAIS DO BRASIL E DA FRANÇA SOBRE O ENSINO DA LÍNGUA ESCRITA NA EDUCAÇÃO INFANTIL?}

$\mathrm{Na}$ França, de acordo com o Programme d'enseignement de l'école maternelle, publicado no Bulletin officiel spécial $n^{\circ} 2$ du 26 mars 2015, o ensino na Educação Infantil deve ser organizado em cinco campos: "Mobilizar a linguagem em todas as suas dimensões"; "Agir, se expressar, compreender por meio da atividade física"; "Agir, se expressar, compreender por meio de atividades artísticas"; "Construir os primeiros instrumentos para estruturar seu pensamento" e "explorar o mundo". Em relação ao primeiro campo, reafirma-se o papel primordial da linguagem nessa primeira etapa da escolarização das crianças como condição essencial do sucesso de todos. De acordo com o referido documento, "o estímulo e a estruturação da linguagem oral, por um lado, e a entrada gradual na cultura escrita, por outro lado, são prioridades da Educação Infantil e dizem respeito a todos os campos".

No que se refere à linguagem oral, entre os objetivos propostos há um relacionado ao desenvolvimento da consciência fonológica: "começar a refletir sobre a linguagem e adquirir uma 
consciência fonológica". Ao tratar desse desenvolvimento, explicitase que para aprender a ler e escrever as crianças precisarão fazer duas importantes aquisições: "identificar as unidades sonoras que são usadas quando se fala francês (consciência fonológica) e compreender que a escrita do francês é um código por meio do qual se transcreve os sons (princípio alfabético)".

O referido documento explicita que para atingir tal objetivo, as crianças devem ser levadas a perceber as sílabas e os fonemas das palavras precisando, para isso, se desprender de seus significados. Destaca-se que a unidade sonora mais facilmente perceptível é a sílaba e que, por isso, as atividades devem envolver, inicialmente, esse segmento sonoro por meio de atividades que levem as crianças a decompor palavras em sílabas, identificar sílabas iguais presentes em diferentes palavras, trocar sílabas de palavras, dentre outras. Esses jogos fonológicos (“jeux phoniques”), de acordo com as orientações oficiais, podem ser praticados em grandes grupos e também em pequenos grupos para que todas as crianças possam participar. Em relação aos fonemas, ressalta-se que aqueles que correspondem às vogais são mais facilmente perceptíveis que os sons correspondentes às consoantes, e, em algumas situações, esses sons-vogais correspondem a uma sílaba. Nesse sentido, propõese começar o trabalho pela percepção desses sons, sem que haja a necessidade de levar as crianças a identificar todos os fonemas, destacando-se os mais acessíveis e perceptíveis.

Quanto à linguagem escrita, propõe-se, como objetivos, que as crianças possam compreender textos escritos lidos para elas (textos literários e de outros gêneros); descobrir as funções da escrita; começar a produzir textos escritos com a ajuda de um adulto; descobrir o princípio alfabético e começar a escrever com autonomia. Em relação à descoberta do princípio alfabético, considerada como uma das condições para se aprender a ler e escrever, o que se espera é que as crianças compreendam que a escrita codifica os sons das palavras, e não os seus significados, sem que seja necessário o ensino sistemático das relações entre formas orais e escritas. Para compreender tal princípio, destaca-se a necessidade do desenvolvimento de uma consciência fonológica que os torne capaz de identificar as unidades sonoras da língua.

Goigoux, Cébe e Paour (2004), ao elaborarem um instrumento didático para ajudar professores do último ano da escola maternal no trabalho com atividades fonológicas, o Phono, consideraram o que tem 
sido prescrito nos programas oficiais para esse nível de ensino - a compreensão de como funciona o código alfabético - e as recomendações presentes nesses documentos de começar o trabalho fonológico pela unidade silábica, seguida de seus constituintes: rimas, fonemas.

Nessa perspectiva, na França a alfabetização não é mais vista como o ensino do código escrito realizado em um ano específico, mas como um processo que se inicia ainda na Educação Infantil. Essa mudança de concepção e prática de ensino, segundo Chartier (2007), tornou, ao mesmo tempo, o papel da turma de alfabetização $(\mathrm{CP})$ mais leve e mais pesado: mais leve no sentido da turma de alfabetização não ser mais "a" classe de alfabetização, e os conhecimentos dos alunos sobre a cultura escrita serem considerados desde a Escola Maternal; e mais pesada, porque o objetivo da turma de alfabetização não pode mais se reduzir ao ensino da codificação e decodificação, mas precisa "articular o trabalho com o código e com a compreensão textual, tanto em sua recepção, como em sua produção” (p. 151).

No Brasil, o Referencial Curricular para a Educação Infantil (1998), no Volume 3, propõe o trabalho com a linguagem como um dos eixos básicos nessa etapa da escolarização, e destaca que

aprender a língua não é somente aprender as palavras, mas também os seus significados culturais, e, com eles, os modos pelos quais as pessoas do seu meio sociocultural entendem, interpretam e representam a realidade (p. 113).

Em relação às crianças de 4 a 6 anos, o referido documento enfatiza o trabalho no eixo da leitura, produção de textos e oralidade, fundamentais para todas as etapas de escolarização e para essa especificamente, mas no que se refere ao eixo da apropriação do sistema de escrita alfabética, diferentemente das prescrições francesas, há pouca ênfase na realização de atividades fonológicas envolvendo um trabalho de reflexão sobre as unidades das palavras, mesmo que em nível oral. Estimula-se a escrita espontânea de palavras e textos e o reconhecimento do próprio nome. Apenas na seção onde há indicações de situações de leitura a serem desenvolvidas em sala de aula, o documento sugere momentos de leitura que envolvam textos da tradição oral que as crianças sabem de cor para que, no momento em que sejam estimuladas a ler o texto, possam estabelecer uma relação entre o que é falado e o que está escrito e para que tentem localizar onde estão escritas determinadas palavras.

O documento da BNCC, publicado em dezembro de 2017, no que se refere à Etapa da Educação Infantil, considera que "as aprendizagens e o desenvolvimento das crianças têm como eixos 
estruturantes as interações e as brincadeiras, assegurando-lhes os direitos de conviver, brincar, participar, explorar, expressar-se e conbecer-se" (p. 36). A organização curricular da Educação Infantil nesse documento está estruturada em cinco campos de experiência: "o eu, o outro e o nós"; "Corpo, gestos e movimentos"; "Traços, sons, cores e formas"; "Escuta, fala, pensamento e imaginação" e "Espaços, tempos, quantidades, relações e transformações". É no campo da "Escuta, fala, pensamento e imaginação" que se faz referência à linguagem oral, ao se propor que na Educação Infantil a criança possa falar e ouvir, potencializando sua participação na cultura oral como sujeito pertencente a um grupo social. A linguagem escrita também é abordada nesse campo, ao ressaltar o interesse e a curiosidade da criança pela cultura escrita:

\footnotetext{
"ao ouvir e acompanhar a leitura de textos, ao observar os muitos textos que circulam no contexto familiar, comunitário e escolar, ela vai construindo sua concepção de língua escrita, reconhecendo diferentes usos sociais da escrita, dos gêneros, suportes e portadores. $\mathrm{Na}$ Educação Infantil, a imersão na cultura escrita deve partir do que as crianças conhecem e das curiosidades que deixam transparecer" (p. 38)
}

Destaca-se a importância das experiências com a literatura infantil para o desenvolvimento do gosto pela leitura, do estímulo à imaginação e da ampliação do conhecimento do mundo, assim como o contato com textos de diferentes gêneros por meio do qual a criança constrói conhecimentos diversos (diferenciação entre ilustração e escrita, aprendizagem da direção da escrita etc.). Parte-se do pressuposto de que por meio da convivência com textos escritos, as crianças "vão construindo hipóteses sobre a escrita que se revelam, inicialmente, por rabiscos e garatujas e, à medida que vão conhecendo letras, em escritas espontâneas, não convencionais, mas já indicativas da compreensão da escrita como sistema de representação da língua" (p. 38)

Diferentemente do documento francês, o texto da BNCC não faz menção explícita ao desenvolvimento da compreensão do princípio alfabético necessário à aprendizagem da leitura e da escrita, nem tampouco aborda a importância das atividades fonológicas para tal compreensão. Em relação à apropriação da escrita alfabética, um dos objetivos de aprendizagem e desenvolvimento relacionados ao campo da "escuta, fala, pensamento e imaginação" envolve, de certa forma, atividades fonológicas ao se propor, em relação às crianças de 4 e 5 anos, o "inventar brincadeiras cantadas, poemas e canções, criando rimas, aliterações e ritmos" (p. 45). Além de tais atividades, ressalta-se a 
importância da escrita espontânea de palavras e textos, por meio da qual é possível "levantar hipóteses em relação à linguagem escrita" (p. 46).

Tanto na França como no Brasil, os documentos curriculares nacionais não propõem que as crianças no último ano da Educação Infantil se alfabetizem, mas sugerem que vivenciem atividades de leitura e escrita de diferentes textos no sentido de compreender os diversos usos e funções da língua escrita. Embora não defendam o ensino da leitura e da escrita com o objetivo de alfabetizar os alunos, o documento francês propõe de forma explícita que as crianças da Educação Infantil possam vivenciar atividades fonológicas que as façam refletir sobre a natureza do sistema de escrita alfabética no sentido de compreender que as letras representam/notam a pauta sonora das palavras, o que não é observado nos documentos brasileiros como o Referencial Curricular para a Educação Infantil (1998) e a BNCC (2017).

Mais recentemente, com a instituição da Política Nacional de Alfabetização (2019), uma mudança no tratamento da linguagem escrita na Educação Infantil pode ser efetivada nas escolas públicas do Brasil. Como abordado na introdução desse artigo, o referido Plano propõe, como dois dos componentes essenciais para a alfabetização, a "consciência fonêmica" e a "instrução fônica sistemática". O parágrafo $2^{\circ}$ do decreto que instituiu o PNA apresenta a seguinte definição para tais termos:

\footnotetext{
IV - consciência fonêmica - conhecimento consciente das menores unidades fonológicas da fala e a habilidade de manipulá-las intencionalmente;

V - instrução fônica sistemática - ensino explícito e organizado das relações entre os grafemas da linguagem escrita e os fonemas da linguagem falada;
}

Vivemos, portanto, um momento em que as orientações nacionais para a alfabetização parecem privilegiar a volta do método fônico de alfabetização. Quais são as implicações dessa ênfase para o trabalho com a linguagem na Educação Infantil? Ao analisar materiais didáticos para essa etapa da escolarização baseados em métodos fônicos, mais especificamente o material do Programa Alfa e Beto destinado a crianças do último ano da Educação Infantil, Brandão e Silva (2017) perceberam de fato que a preocupação incide sobretudo no reconhecimento dos fonemas nas palavras e na memorização de sua forma escrita. Para isso, os referidos autores identificaram um quantitativo muito elevado de atividades nas quais as crianças devem, por exemplo, identificar determinados fonemas no início, no meio ou no final de palavras, contar o número de vezes em que eles aparecem em uma palavra, reconhecer palavras que comecem com 
o mesmo fonema. Além disso, eles apontaram a presença de textos artificialmente produzidos para ensinar a ler, com léxico controlado e frases justapostas. Com isso, ao longo do ano, as crianças são "expostas a textos nos quais o sentido do que se diz deixa de ser importante, já que o que conta é a presença de palavras que reforcem a pronúncia do fonema que se quer ensinar" (p. 447).

Sobre a relação entre consciência fonológica e alfabetização, pesquisas desenvolvidas por Morais (2004) mostram que a consciência fonêmica explícita é mais uma consequência que requisito para a alfabetização e reforçam a ideia de que a reflexão sobre segmentos maiores (sílabas, rimas) pode e deve ser promovida antes do ano letivo da alfabetização formal. Sugerem, ainda, a importância de a instituição escolar promover, desde a educação infantil, a reflexão sobre palavras, rimas e sílabas semelhantes, principalmente por meio de jogos e brincadeiras, de forma lúdica.

Soares (2016) destaca que a criança, desde cedo, revela sensibilidade fonológica às sílabas, sendo capaz de dividir uma palavra nesse segmento, o mesmo não acontecendo com a sensibilidade a fonemas, pelo fato de "os fonemas não serem separados fisicamente na cadeia da fala" (p. 193). Assim como Morais (2004, 2012), ela propõe que desde a Educação Infantil haja um trabalho na perspectiva do alfabetizar e letrar, com atividades envolvendo a leitura de diferentes textos, entre eles os da tradição oral que propiciam reflexão sobre a sonoridade das palavras.

Que experiências de ensino da leitura e da escrita as crianças da Educação Infantil têm vivenciado em escolas do Brasil?

\section{PRÁTICASDE ENSINODA LEITURA E DA ESCRITA NO ÚLTIMO ANODA EDUCAÇÃO INFANTIL: $O$ QUE REVELAM ALGUMAS PESQUISAS}

Pesquisas têm analisado o trabalho com a língua escrita no último ano da Educação Infantil em escolas do Brasil. Aquino (2008) investigou as práticas de ensino da leitura e da escrita desenvolvidas por duas professoras que lecionavam nesse nível de ensino, na rede municipal de Recife-PE. Como procedimentos metodológicos foram realizadas observações de aulas, entrevistas, e atividades de escrita com apoio de gravuras com os alunos, para avaliar o nível de escrita deles no início e no final do ano letivo. Os resultados da pesquisa indicaram práticas diferenciadas de ensino da linguagem e uma diferença nos desempenhos dos alunos nas atividades de escrita de palavras. A 
prática da professora da turma A era mais voltada para o terceiro caminho apontado por Brandão e Leal, e envolvia, além da hora do conto realizado diariamente, a leitura de gêneros que faziam parte do universo infantil - parlendas, cantigas, poemas - ao mesmo tempo em que explorava algumas características desses textos, como as rimas. A professora da turma $\mathrm{B}$ também realizava um trabalho diário de leitura de textos na perspectiva do letramento, mas no que se refere ao ensino da escrita alfabética, realizava atividades de leitura e cópia de padrões silábicos de palavras chave extraídas dos textos. Quanto aos alunos, constatou-se uma evolução dos alunos da turma A no que se refere à compreensão da escrita alfabética durante o ano, uma vez que a maioria deles concluiu essa etapa na hipótese silábica de escrita, enquanto na outra turma a maioria concluiu o ano com hipóteses iniciais de escrita.

O trabalho de Lima (2010) também teve o objetivo de analisar práticas diferenciadas de ensino voltadas à compreensão do sistema de escrita alfabética desenvolvidas em duas turmas do último ano da Educação Infantil e suas relações com as aprendizagens dos alunos. Participaram do estudo duas professoras que lecionavam no último ano da Educação Infantil, sendo uma da rede municipal do Recife e a outra da rede privada do município de Olinda-PE. Ambas as escolas atendiam crianças do meio popular. Como procedimentos metodológicos, foram realizadas entrevistas com as professoras, observações de aulas e aplicação de uma atividade de escrita de palavras no início e no final do ano letivo com os alunos de ambas as turmas com o objetivo de analisar o desempenho dos mesmos no processo de aquisição da escrita. A prática de ensino da professora da rede privada era baseada em uma cartilha silábica e envolvia, a cada semana, o trabalho com uma família silábica específica por meio de atividades repetitivas com ênfase na memorização e cópia de sílabas e palavras. Já a professora da rede pública promovia a leitura de diferentes gêneros textuais e realizava atividades lúdicas e reflexivas que envolviam o trabalho com rimas e jogos fonológicos. Quanto às aprendizagens dos alunos, a turma da rede pública obteve melhores resultados em relação ao outro grupo, uma vez que todos os alunos concluíram o ano letivo demonstrando conhecer que a escrita tem relação com a pauta sonora das palavras, enquanto que na escola privada, $46 \%$ das crianças apresentavam, no final do ano, hipóteses iniciais de escrita.

Os resultados desses estudos apontam, por um lado, que as professoras têm buscado vivenciar atividades significativas de leitura e, em menor quantidade, de produção de textos. No que se refere à alfabetização, percebemos, no entanto, que enquanto algumas 
docentes buscavam realizar atividades lúdicas e reflexivas que possibilitavam a apropriação do SEA, outras permaneciam presas ao ensino transmissivo e repetitivo de letras, sílabas ou palavras. Percebese, assim, a necessidade de se investir, nos cursos de formação de professores, na discussão sobre como tratar os conhecimentos relativos ao ensino da escrita alfabética com crianças da Educação Infantil.

Soares (2014) vem realizando, desde 2007, um projeto com professores do município de Lagoa Santa-MG, denominado Projeto Alfaletrar por entender a aprendizagem da língua escrita como uma articulação entre alfabetizar e letrar. Em relação à alfabetização, a referida autora enfatiza que a criança precisa entender a natureza do nosso sistema de escrita alfabética (que a escrita representa a pauta sonora das palavras) e descobrir que a cadeia sonora das palavras pode ser segmentada em sílabas e estas em fonemas. Em seguida, precisa aprender as normas ortográficas que envolve as convenções para uso do sistema alfabético. Tais aprendizagens não devem ocorrer, no entanto, antes ou dissociadas das práticas de leitura e escrita, mas sim em contexto de letramento, "por meio da convivência e experiências com material escrito, diferentes portadores de texto, diferentes gêneros, ao mesmo tempo ampliando sua compreensão dos usos sociais da escrita e seu interesse por eles" (p. 154).

Um aspecto a ser destacado do projeto Alfaletrar é a garantia de que o ensino funcione realmente em ciclos, com continuidade e integração dentro de cada ciclo e entre um ciclo e outro. Para isso, a autora destaca a importância da definição de metas de aprendizagem, estabelecidas para cada ciclo e ano de ensino, que propõem o que toda criança tem o direito de aprender em cada fase de seu desenvolvimento. Em Lagoa Santa, em relação à alfabetização e letramento, as metas foram construídas na implantação do Projeto e envolvem os diferentes eixos do ensino da Língua Portuguesa. As atividades de consciência fonológica devem estar presentes desde o maternal, por meio do trabalho com parlendas, poemas, cantigas, não apenas para o desenvolvimento da oralidade, mas também para que a criança perceba a cadeia sonora da fala. Soares destaca, portanto, a importância do desenvolvimento de atividades que buscam levar a criança a focalizar os sons das palavras, base para a aprendizagem da escrita. Além das atividades fonológicas, considera importante o trabalho com o alfabeto, levando a criança a compreender que as letras não são objetos, mas representações arbitrárias em que uma rotação horizontal ou vertical transforma a letra em outra. 
Por meio de avaliações diagnósticas realizadas ao longo do ano, com instrumentos elaborados pelas professoras no âmbito do Projeto, as docentes fazem o acompanhamento das aprendizagens dos alunos. Os resultados das avaliações indicam uma melhoria da qualidade da educação no município de Lagoa Santa, com avanço significativo na aprendizagem das crianças e na competência das professoras. Houve evolução do Ideb do município, com superação, em 2013, da meta projetada e a evolução no desempenho em leitura na Prova Brasil tem sido crescente. Soares destaca a importância de os professores conhecerem os processos linguísticos e cognitivos da aprendizagem inicial da língua escrita para "traduzi-los em procedimentos, métodos, atividades que promovam e acompanhem o desenvolvimento das crianças" (p. 170).

Diante do exposto, defendemos, como Soares (2014), que na Educação Infantil as crianças possam vivenciar atividades que envolvam o brincar com as palavras e suas sonoridades, na perspectiva de ultrapassar um ensino transmissivo de letras e sons ainda frequente em muitas turmas dessa etapa de escolarização, como observado por Lima (2010), e em materiais didáticos destinados às crianças da Educação Infantil, como os do "Programa Alfa e Beto Pré-Escola", analisados Brandão e Silva (2017). Não estamos, com isso, propondo uma "antecipação" da alfabetização para o final da educação infantil, no sentido de levar as crianças de cinco anos a atingirem uma hipótese alfabética de escrita e automatizarem todas as correspondências som-grafia do português. Ao contrário, propomos que sejam garantidas aos alunos dessa etapa oportunidades para, de forma lúdica e desafiadora, atuarem como sujeitos da linguagem numa dimensão mais reflexiva, em um contexto que envolva a leitura e exploração de diferentes textos e de palavras.

Nesse artigo, apresentaremos dados de uma pesquisa que buscou analisar práticas de ensino da leitura e da escrita em turmas do último ano da Educação Infantil e a relação dessas práticas com os conhecimentos apresentados pelos alunos ao final do ano letivo em relação à apropriação do Sistema de Escrita Alfabética (SEA). A pesquisa envolveu duas escolas públicas - uma do Brasil (em Recife-PE) e outra da França (em Paris) - que atendiam crianças do meio popular.

\section{METODOLOGIA}

Apresentaremos, nessa seção, as escolas campo da pesquisa, os perfis das professoras e das turmas que participaram do estudo e os procedimentos metodológicos utilizados. 
A escola do Brasil foi construída na década de 1970 e integrava um complexo educacional que tinha como objetivo servir de referência em jardim de infância na educação pública no estado de Pernambuco. Ela pertencia à rede estadual de ensino e em 2001 foi municipalizada, passando a pertencer à Secretaria de Educação da cidade do Recife. Era uma escola relativamente grande, com espaços comuns amplos para as crianças brincarem na hora do recreio e onde elas eram recebidas no início da jornada escolar. Havia uma sala de leitura com vários livros de literatura infantil e materiais de apoio para a leitura e contação de histórias.

A escola francesa era localizada em um bairro popular, em uma zona industrial, chamada Noisy-le-Grand Mont d'Est. Ela era considerada uma escola de $\mathrm{ZEP}^{3}$ (Zona de Educação Prioritária) que atendia, principalmente, a crianças da classe popular (imigrantes ou filhos de imigrantes). Em meio a um conjunto residencial popular, a escola foi construída pelas indústrias da região e era mantida pelo estado. A escola se diferenciava, em sua arquitetura, da maioria das escolas da França, com ambientes bem coloridos, salas de aula amplas, espaço de recreação bem equipado, sala de leitura, de ciências e refeitório.

As duas professoras participantes da pesquisa eram muito experientes, possuindo mais de 20 anos de trabalho como docentes da Educação Infantil ou dos anos iniciais do Ensino Fundamental. A professora do Brasil, (doravante PB), era formada em Pedagogia e também em Biologia, e atuava como docente da rede estadual de Pernambuco (à tarde) e de uma escola da rede privada (de manhã), ambas localizadas em Recife. Na rede pública, ela lecionava em turmas do último ano da Educação Infantil há apenas três anos, mas na escola da rede privada, ela atuava como docente do último ano da Educação Infantil ou do $1^{\circ}$ ano do Ensino Fundamental há 15 anos. Na época da pesquisa, ela era professora da turma de alfabetização $\left(1^{\circ}\right.$ ano $)$ dessa escola. A escolha por essa professora se deu exatamente por sabermos de sua experiência na escola da rede privada que possuía uma proposta pedagógica baseada em uma abordagem sociointeracionista e na Pedagogia de Projetos. A professora, na entrevista realizada antes de iniciarmos a pesquisa, nos disse que buscava desenvolver com os alunos da escola púbica uma prática de certa forma parecida com a que realizava na escola da rede privada.

A turma da referida professora era composta por 19 alunos com idades entre cinco e seis anos. A sala de aula era ampla, possuía um grande quadro de giz na altura dos alunos, uma estante com alguns brinquedos e jogos, dois armários para guardar os materiais 
das professoras (um para a docente da manhã e outro para a da tarde), cabides para os alunos pendurarem suas bolsas e uma estante para eles guardarem as pastas com as atividades que realizavam. Essa estante continha fichas (algumas acompanhadas de fotos) com os nomes dos alunos, indicando onde deveriam colocar seus materiais. Nas paredes da sala havia cartazes com textos lidos, um alfabeto com letras de forma grandes fixado em cima do quadro, um calendário ao lado esquerdo dele e um cartaz com a lista dos nomes dos alunos da sala.

A professora da França, (doravante PF), era formada em letras - língua francesa - e atuava como professora há mais de vinte anos. Também era formadora de professores no Instituto de Formação de Professores (IUFM) da Académia de Créteil. ${ }^{4}$ Ela ensinava em uma turma da Grand Séction (último ano da Educação Infantil), todos os dias da semana no horário das 8 h30 às 16 h30 (com intervalo de almoço), com exceção das quartas-feiras, dia em que não havia aula nas escolas de Educação Infantil (École Maternelle) e do primeiro segmento do Ensino Fundamental (École Élémentaire) na França.

A turma de PF possuía 25 alunos com idades entre cinco e seis anos (completos ao final do ano letivo). A sala de aula era ampla e bem iluminada. Havia um quadro branco em uma das paredes e, em frente a ele, havia três bancos compridos organizados em forma de $\mathrm{U}$ para os alunos se sentarem. As atividades coletivas eram realizadas nessa "roda", com a professora sentada na frente deles, e as atividades individuais e em grupos eram realizadas em mesas que tinham tamanhos diferentes. Havia, na sala, uma estante com livros de literatura, outra organizadas em escaninhos individuais, com o nome de cada aluno, para eles guardarem as atividades realizadas, e cantinhos com jogos, brinquedos, dois computadores, além de uma mesa com uma tampa com espaços abertos onde eram guardados os materiais escolares como lápis, borrachas, tesouras, etc. Nas paredes havia muito material escrito: alfabeto, cartazes com textos diversos (receita, histórias, lista de alunos, meses do ano com aniversariantes, etc.), atividades realizadas pelos alunos, etc. Em uma das paredes da sala havia um grande alfabeto ilustrado.

Enquanto no Brasil, a sala de aula era compartilhada por duas professoras (uma que lecionava no turno da manhã e outra no turno da tarde), na França, como a escola pública funciona em horário integral, a sala era utilizada por apenas uma professora e sua turma.

Como procedimentos metodológicos, realizamos observações de aulas, entrevistas com as professoras e análise documental referente às atividades vivenciadas pelas crianças no período das observações, 
incluindo uma avaliação da escrita por nós aplicada. Na escola do Brasil, as observações de aulas aconteceram em três semanas ao longo de um ano letivo (nos meses de março, agosto e novembro), totalizando quinze dias de observação. No caso da escola da França, iniciamos as observações em fevereiro, fomos em média uma vez por semana (totalizando 10 dias de observação) e acompanhamos a turma até o final do ano letivo (junho). ${ }^{5}$ Para cada dia de aula observada, foram feitos registros em diários de campo e fotografias dos espaços e das atividades para posterior análise. No final do ano letivo, em ambas as turmas, avaliamos os conhecimentos dos alunos sobre o SEA por meio da aplicação de uma atividade de escrita de palavras com apoio de figuras.

As escritas dos alunos nessa atividade foram analisadas com base nos trabalhos de Ferreiro e Teberosky (1984) sobre a psicogênese da língua escrita. Categorizamos as notações escritas das crianças a partir dos conhecimentos que demonstraram ter em relação aos princípios do SEA. Identificamos, portanto, as seguintes categorias: 1. Escritas com uso de letras ou outros símbolos sem correspondência sonora; 2. Escritas com correspondência sonora na primeira sílaba da palavra; 3. Marcação de uma letra para cada sílaba, com predomínio de letras com valor sonoro convencional e 4 . Notação das sílabas das palavras demonstrando compreender que as sílabas são formadas por unidades sonoras menores (compreensão do princípio alfabético).

$\mathrm{Na}$ seção a seguir, apresentaremos os resultados da pesquisa organizados nos seguintes tópicos relacionados às atividades desenvolvidas pelas docentes e aos conhecimentos dos alunos: "a rotina e as atividades iniciais de cada dia", "O trabalho com a leitura", "as atividades voltadas para apropriação da escrita alfabética" e "os conhecimentos das crianças sobre a escrita alfabética".

\section{O ENSINO DA LEITURA E DA ESCRITA E OS CONHECIMENTOS DOS ALUNOS}

\section{A ROTINA E AS ATIVIDADES INICIAIS DE CADA DIA}

Inicialmente iremos discorrer sobre como as duas professoras organizavam suas práticas pedagógicas, mais especificamente aquelas relacionadas ao ensino da leitura e da escrita, assim como as atividades que eram realizadas no início de cada jornada escolar.

PB relatou, no momento da entrevista, que organizava sua prática por meio do desenvolvimento de projetos didáticos como os que ela vivenciava na escola da rede privada. Assim, ao longo do ano, ela propunha para os alunos a realização de dois ou três projetos que 
envolviam a leitura de diferentes textos e a realização de atividades diversas relacionadas às diferentes áreas de conhecimento. No ano em que realizamos as observações, os projetos foram: "Vida de criança" e "Animais marinhos e terrestres". Como atividades permanentes, diariamente ela fazia a leitura de um livro de literatura infantil, realizava uma atividade relacionada ao projeto ou a uma área de conhecimento, além de propor atividades lúdicas (brincadeiras ou jogos).

No início de cada jornada escolar, depois que os alunos guardavam seus materiais (bolsas e pastas) e sentavam em uma roda, PB iniciava as atividades de escrita e leitura do cabeçalho, sempre perguntando às crianças o nome da escola e a data do dia. Em seguida, ela iniciava a escrita da agenda/rotina do dia com a ajuda dos alunos. Para isso, perguntava o que fariam naquele dia da semana. Como essa produção era feita diariamente, as crianças conseguiram, em sua maioria, internalizar as atividades que eram realizadas diariamente e outras que aconteciam em dias específicos, como a aula de recreação, e podiam ajudar a professora na escrita dessa agenda. Algumas palavras que eram escritas diariamente foram memorizadas por alguns alunos, se transformando, para eles, em palavras estáveis. O exemplo a seguir apresenta a escrita de uma dessas agenda/rotina:

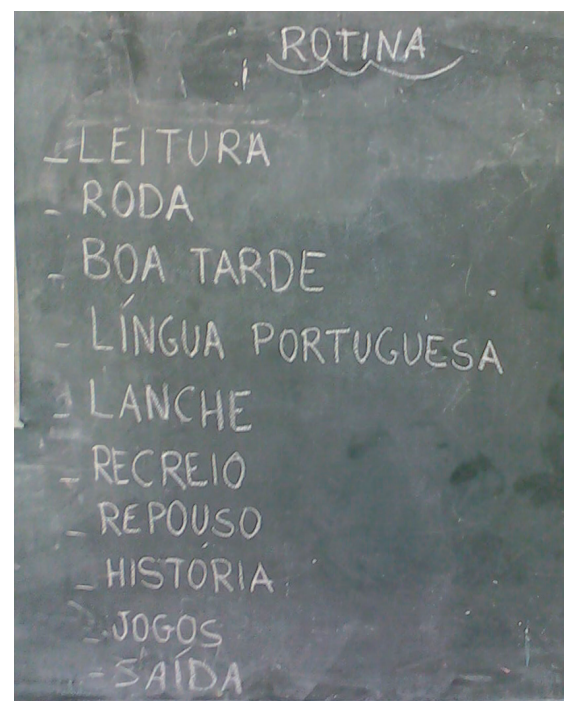

Figura 1

A professora escrevia a palavra ROTINA no quadro e a lia marcando as sílabas com pequenos traços abaixo delas, como pode ser observado na imagem. Tanto essa palavra, como outras que se repetiam diariamente (RODA, RECREIO, REPOUSO), foram 
memorizadas por alguns alunos. A professora também explorava as semelhanças sonoras entre algumas dessas palavras (REPOUSO, RECREIO e RECREAÇÃO, por exemplo), assim como entre elas e os nomes dos alunos. O interessante é que, muitas vezes, quando ela começava a escrever uma palavra, como RECREIO, ao verem a primeira letra ou sílaba, algumas crianças faziam antecipações/ sugestões. No final do dia, em geral, ela lia novamente a Rotina escrita no quadro para ver com as crianças o que foi feito e saber o que elas acharam das atividades vivenciadas ao longo do dia.

Quando terminava a escrita da rotina, PB fazia a chamada informal dos alunos, por meio de diferentes estratégias. No início do ano, ela usava as fichas com os nomes dos alunos para que eles encontrassem, cada um, o seu nome. As fichas que sobravam deveriam ser lidas pelos alunos e, com isso, eles identificavam os alunos ausentes, e faziam a contagem dos alunos presentes, destacando a quantidade de meninos e meninas. Em outro momento, ela pegou as fichas com os nomes e foi mostrando cada uma e perguntando qual era o nome que estava escrito. Ela mostrou a ficha com o nome EMMANUEL e o aluno disse: "Sou eu!". Foi mostrando cada nome, os alunos liam e ela colocava a ficha em uma das três colunas escritas por ela no quadro: MENINOS, MENINAS, AUSENTES. Ela mostrou ALIANDRO, os alunos disseram ACACIA, e ela pediu para lerem de novo. Em outro dia, ela mostrava apenas a primeira letra do nome do aluno para eles adivinharem de quem era a ficha. $\mathrm{Na}$ segunda e terceira semanas de observação, a atividade da chamada era realizada com a professora escrevendo no quadro, com a ajuda dos alunos, os nomes dos alunos presentes e, em um lugar separado, os dos alunos ausentes. Outra forma de fazer a chamada envolvia a contagem dos alunos (meninos e meninas) presentes, e a escrita no quadro apenas dos nomes dos alunos ausentes.

PF organizava sua prática pedagógica por meio de diferentes atividades, com ênfase no desenvolvimento de ateliers, sobre os quais falaremos mais detalhadamente na seção 5.3. Como atividades permanentes, os alunos vivenciavam, no início de cada manhã, sentados na "roda" (bancos em formato de U), as atividades de rotina (rituels): calendário, contagem dos alunos presentes e daqueles que iriam almoçar na escola ou que ficariam depois do horário em atividades complementares por solicitação da família. Havia um quadro na parede que diariamente era preenchido com esses dados. Em geral, a professora escolhia uma criança para fazer o preenchimento desse quadro. A chamada era realizada pela professora diariamente por meio de diferentes estratégias/brincadeiras, muitas delas envolvendo atividades fonológicas. Em um dia, por exemplo, ela 
disse que iria falar os nomes dos alunos com as sílabas invertidas para eles descobrirem o nome correspondente; em outro dia, a professora falou a primeira sílaba e pediu para eles completarem a palavra, dando pistas relacionadas a características da criança; em outro momento, a docente usou a estratégia de falar o nome de cada aluno escandindo as sílabas e os alunos deveriam juntá-las para dizerem o nome que a professora chamou. Podemos perceber que esse momento da chamada era transformado em uma atividade lúdica que ao mesmo tempo em que divertia as crianças, proporcionava que elas refletissem sobre as unidades sonoras dos nomes dos alunos da turma. Com essas atividades, PF, como PB, possibilitava que os nomes dos alunos da turma se transformassem em palavras estáveis que podiam servir de referência para a leitura e escrita de outras palavras.

\section{O TRABALHO COM A LEITURA}

As duas professoras realizaram, ao longo das observações, a leitura de livros de literatura assim como de outros textos, como poemas, parlendas, textos instrucionais.

PB lia diariamente um livro de literatura, em geral depois do recreio e do momento de repouso. O livro podia ter relação com o projeto didático que estava sendo desenvolvido ou não. Na primeira semana de observação, a professora leu livros no âmbito do projeto "Vida de Criança", como o livro "Eu quero! Eu quero!", de Shirley Souza, e "Joaquim, o rei do pinguim", de Armelle Boy. Na sétima visita o livro lido foi "O caracol", de Mary França, que tinha relação com o projeto "Animais marinhos e terrestres".

Em relação aos poemas e parlendas, no segundo semestre PB começou a produzir com os alunos um caderno individual contendo poemas e parlendas que eram lidos/trabalhados ao longo das semanas. Em geral, ela lia o poema para os alunos, que deveriam memorizá-los para, no final da semana, levarem o caderno para casa para lerem os poemas, com apoio da memória, para seus familiares. Além da leitura e memorização desses textos, $\mathrm{PB}$ realizava atividades de exploração de algumas de suas características, como a presença de rimas ou a identificação de palavras que se repetiam ou que começavam com a mesma sílaba. Os poemas lidos/trabalhados, além de serem colados nos cadernos de leitura, eram escritos em cartazes na sala. A professora sempre procurava relembrar com as crianças os textos presentes no caderno de leitura. Na Rotina apresentada na Figura 1, a primeira atividade - Leitura - correspondia à leitura de poemas desse caderno.

PF também realizava a leitura de livros de literatura (os "albums pour enfants") pelo menos duas vezes por semana, e os 
livros lidos ficavam disponíveis para os alunos manusearem em uma pequena estante, junto com outros livros. A cópia da capa de cada livro lido era inserida em um mural. As crianças podiam recorrer a esse mural como apoio para a escrita de palavras presentes nas capas, assim como manuseavam livremente os livros disponíveis na estante. $\mathrm{Na}$ imagem da sala de aula apresentada a seguir, pode-se ver tanto a estante com os livros, como o referido mural.

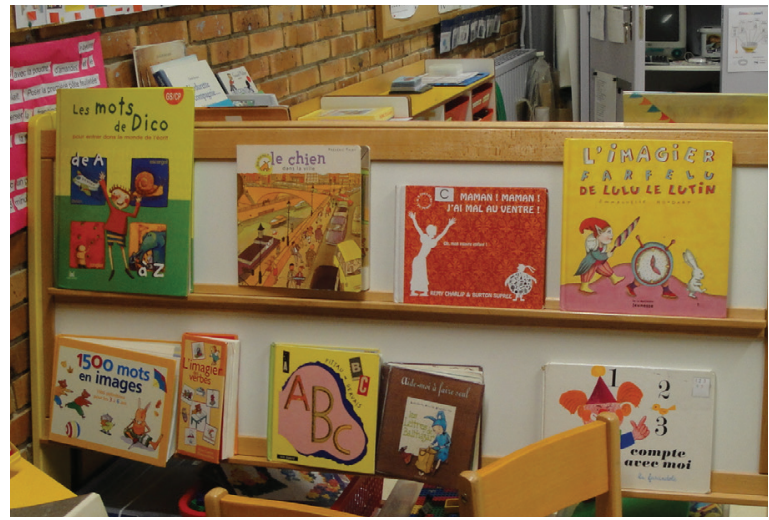

Figura 2

A leitura de poemas e de parlendas (comptines) também era realizada por PF. Durante o período das observações, acompanhamos, por exemplo, um trabalho que envolveu a leitura e memorização de um poema que seria apresentado para os pais no final do ano letivo. $\mathrm{O}$ poema era o seguinte:
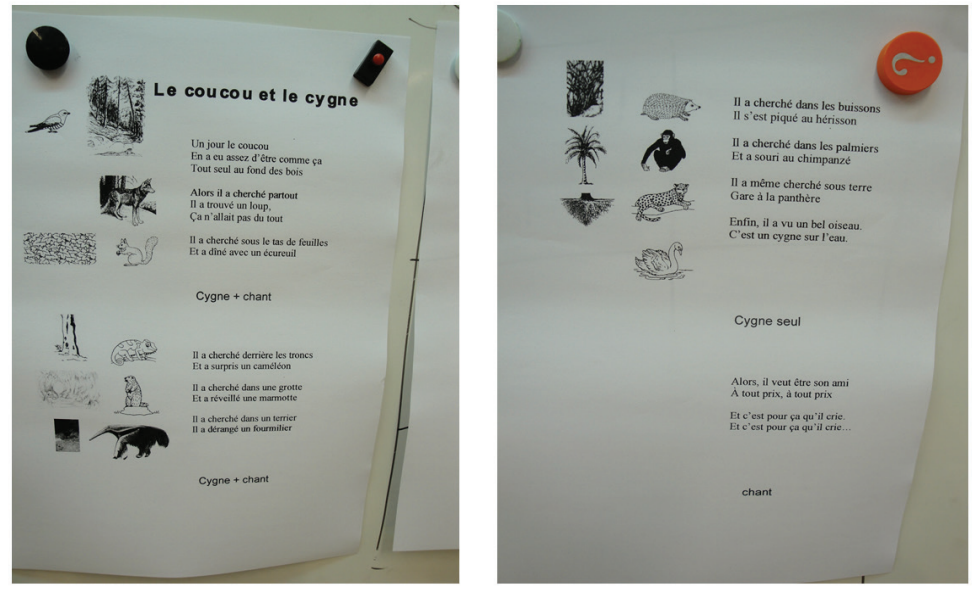

Figura 3 
De início, PF fez a leitura e exploração do poema chamando a atenção dos alunos para as rimas (o poema é todo rimado) e para as figuras presentes ao lado dos versos que indicavam exatamente as palavras que rimavam. Trata-se de um poema de fácil memorização, uma vez que além das palavras que rimam, há a repetição de palavras e expressões, como a que inicia cada par de versos que rimam ("Tl a cherché dans...").

Os alunos apreciaram muito o poema, e se envolveram na atividade de leitura e de sua memorização. Em outro dia, PF apresentou três cartazes contendo apenas as figuras presentes ao lado do poema para, com base nelas, os alunos recitarem o poema que já tinham memorizado.
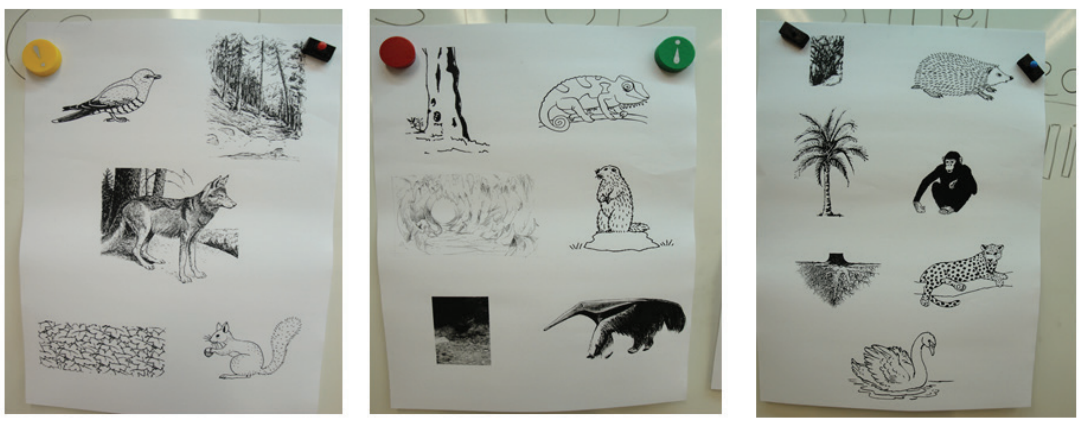

Figura 4

\section{AS ATIVIDADES VOLTADAS PARA APROPRIAC̣̃̃O DA ESCRITA ALFABÉTICA}

Em relação às atividades de apropriação da escrita alfabética, elas eram realizadas, na prática de $\mathrm{PB}$, em diferentes momentos do dia e da semana, podendo se relacionar com os textos lidos ou com outras atividades, como a escrita da rotina e a realização da chamada, descritas anteriormente. Elas também eram realizadas coletivamente, em grupos ou individualmente, principalmente as que eram propostas como "fichas de atividades". Na primeira semana de observação, PB propôs atividades diferentes que envolviam a escrita e exploração dos nomes dos alunos, tanto no momento da chamada, como em outras situações, como a que envolveu um bingo com os nomes das crianças, ou a formação dos nomes com as letras do alfabeto móvel. Em relação a essa última atividade, enquanto a maioria dos alunos formou seus nomes organizados em pequenos grupos, com apoio da ficha do nome, PB realizou a atividade junto a dois alunos que, segundo ela nos relatou, ainda escreviam por meio de rabiscos. Para eles, PB, no lugar de entregar a caixa com as letras do alfabeto móvel, selecionou apenas as letras de seus nomes e os ajudou a formá-los, 
pedindo para que olhassem para os nomes escritos nas fichas. Ela fazia questões como: qual é a primeira letra do seu nome? Quantas letras tem o seu nome?

Durante as três semanas de observação, os alunos realizaram atividades de leitura de textos e de palavras dos textos, identificação de letras e sílabas em palavras, identificação de palavras que rimavam, dentre outras. Na segunda semana de observação, por exemplo, PB realizou várias atividades envolvendo a temática "brinquedos e brincadeiras". Ela leu com os alunos os poemas "Saco de brinquedos" e "Bola", que foram colados no caderno de leitura (que continha os poemas lidos). Em relação ao poema "Bola", os alunos fizeram uma atividade de montar o texto por meio da organização de seus versos, como pode ser observado na Figura 5. Ela fez, também, as seguintes atividades: pesquisa com a turma sobre os brinquedos e brincadeiras preferidos dos alunos; exploração de dois quadros de Candido Portinari - "Meninos soltando Pipa" e "Meninos soltando Papagaio"para, a partir deles, as crianças confeccionarem seus próprios quadros sobre a temática das brincadeiras; confecção de uma peteca com as crianças com base na leitura de um texto instrucional que ensinava a fazer esse brinquedo; atividades individuais em fichas envolvendo a escrita e exploração de palavras relacionadas ao tema, como a apresentada na Figura 6.

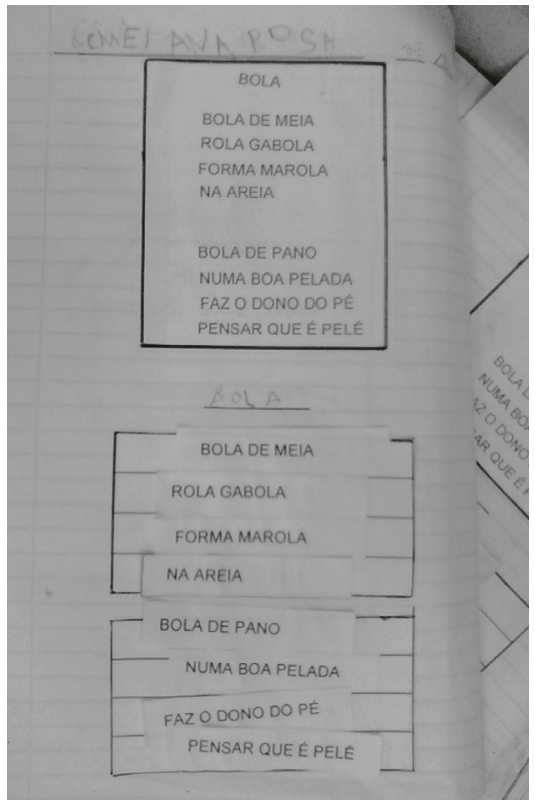

Figura 5 


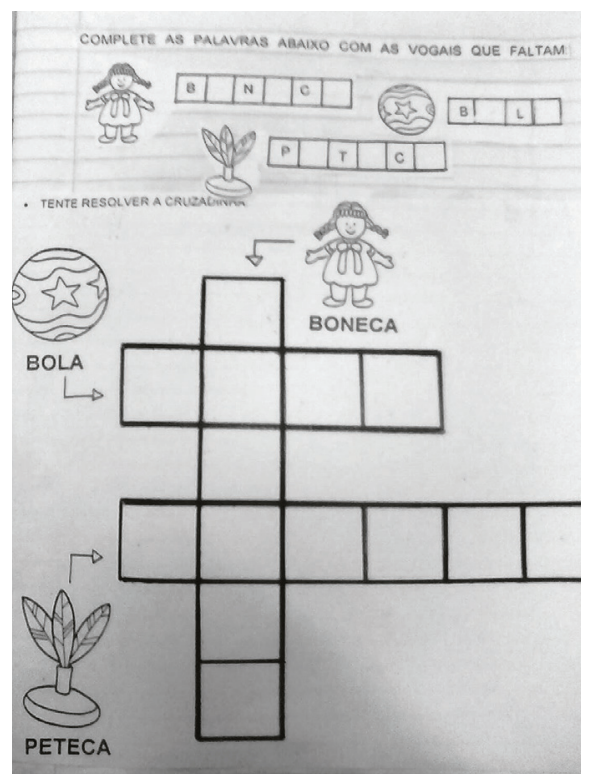

Figura 6

Em novembro, PB realizou uma sequência de atividades que envolveu a leitura de uma quadrinha. Ela fixou o texto no quadro, fez a leitura dele e, em seguida, pediu que as crianças repetissem a quadrinha com ela, que era de fácil memorização. Após levar os alunos a identificarem as palavras que rimavam (SEREIA e BALEIA), ela pediu que eles dissessem palavras que rimavam com essas duas e, depois, solicitou que dissessem outras que começavam com as mesmas sílabas dessas duas palavras. No dia seguinte, as crianças fizeram uma ficha individual envolvendo a leitura da quadrinha e a exploração de algumas palavras do texto.

Essas atividades de apropriação da escrita alfabética, propostas em fichas individuais, não eram realizadas diariamente e estavam relacionadas, em sua maioria, aos projetos e textos lidos em sala de aula. A professora tentava acompanhar os alunos na realização dessas atividades e, para isso, organizava as crianças em pequenos grupos. Enquanto alguns grupos brincavam com jogos em algumas mesas, ela realizava as atividades com as crianças em outras mesas. À medida que os alunos iam terminando a atividade, ela chamava outras para virem fazê-la.

Em relação à prática de $\mathrm{PF}$, nas quintas e sextas-feiras ela organizava o trabalho relacionado à escrita em três ateliers: o atelier de grafismo, o de escrita e o do princípio alfabético que envolvia atividades fonológicas. No atelier de grafismo, os alunos realizavam atividades que 
envolviam desenhos de movimentos geométricos (retas, curvas e círculos) com lápis coloridos que formavam pequenas obras de arte que eram expostas nas paredes da sala. $\mathrm{O}$ Atelier de escrita envolvia a produção, por cada aluno, de um abecedário em um caderno pequeno. A cada semana em que a criança participava desse atelier, ela deveria escolher uma letra do alfabeto e preencher, no caderno, a página correspondente a essa letra com gravuras cujas palavras eram iniciadas por ela, além de escrever a letra em diferentes formatos. No atelier fonológico os alunos eram solicitados, em grupos, a produzir um cartaz com figuras que possuíam um determinado som no início ou final da palavra, ou que possuíam uma quantidade determinada de sílabas. A professora definia os alunos que iriam participar de cada atelier e apresentava os grupos em um cartaz, no início da aula.

Os três ateliers tinham objetivos diferentes relacionados à aprendizagem da escrita: no de grafismo os alunos desenvolviam a coordenação motora, o de escrita envolvia o trabalho com as letras do alfabeto, incluindo também seu traçado, e o fonológico explorava a reflexão sobre a pauta sonora das palavras de modo a levar os alunos a perceberem que palavras diferentes compartilham sons. A professora nos relatou que enquanto os alunos nos dois primeiros ateliers podiam trabalhar de forma mais autônoma, ela dava mais atenção aos alunos do terceiro atelier, mediando a reflexão sobre a relação entre a escrita e os sons das palavras.

Em relação ao atelier fonológico, a cada semana os alunos deveriam realizar uma atividade que envolvia a produção de um cartaz com figuras cujas palavras começavam ou terminavam com determinado som ou possuíam determinada quantidade de sílabas. A ênfase era mais na consciência silábica e nas rimas. Outras atividades fonológicas eram desenvolvidas por meio de brincadeiras (como a da hora da chamada) ou pela exploração de textos da tradição oral (poemas, parlendas).

Além dos ateliers, os alunos realizavam atividades individuais em fichas que envolviam, por exemplo, a leitura e escrita de palavras presentes nos textos lidos, identificação de sílabas e letras em palavras com apoio de gravuras, leitura e escrita dos nomes dos alunos da turma, etc. Essas atividades com fichas não eram realizadas diariamente e no geral envolviam palavras extraídas de situações vivenciadas em sala de aula. Eles produziram, por exemplo, uma sopa de legumes e para isso, leram uma receita da sopa, executaram a receita e depois produziram coletivamente um relato da experiência realizada. Fizeram, também, atividades individuais de escrita de palavras relacionadas a alguns ingredientes da receita. 
Além das atividades mencionadas, os alunos, em duplas, jogavam no computador da sala jogos que envolviam o uso da linguagem em situações em que eram desafiados a relacionar palavras a desenhos para atender a diferentes objetivos.

\section{OS CONHECIMENTOS DAS CRIANÇAS SOBRE A ESCRITA}

Apresentaremos, nessa seção, os conhecimentos das crianças em relação à escrita alfabética, por meio da análise da atividade de escrita de palavras que elas realizaram

Das treze crianças da escola do Brasil que participaram dessa atividade, quatro concluíram o ano escrevendo palavras com letras diferentes (principalmente as que compunham seus nomes), sem correspondência sonora; duas crianças concluíram o ano apresentando escritas com correspondência sonora na primeira sílaba das palavras; duas marcaram uma letra para cada sílaba das palavras com correspondência sonora e cinco crianças apresentaram escritas demonstrando compreender o princípio alfabético. É importante destacar que, conforme nos relatou a professora, duas crianças iniciaram o ano escrevendo por meio de rabiscos.

Quanto aos conhecimentos das crianças da França sobre o SEA, a análise das atividades de escrita de palavras revelou que das vinte crianças que participaram da atividade no final do ano letivo, cinco apresentavam escritas com correspondência sonora na primeira sílaba das palavras, oito crianças concluíram o ano marcando, com uma letra, sons correspondentes a sílabas das palavras e sete alunos escreveram demonstrando perceber que as palavras são formadas por sílabas e estas por unidades menores.

Esses dados mostram que a maioria das crianças da turma do Brasil, e todas as crianças francesas concluíram o ano percebendo que a escrita nota a pauta sonora das palavras, ainda que não apresentassem escritas alfabéticas.

\section{CONSIDERAC̣ÕES FINAIS}

Retomaremos, nessa parte final do artigo, algumas questões levantadas na introdução: $\mathrm{O}$ que que fazer com as crianças de 4 e 5 anos em relação ao trabalho com a língua escrita? Quando e como alfabetizar nossos alunos? Qual o momento de iniciar esse processo? É para alfabetizar as crianças na Educação Infantil? 
Considerando as diferenças socioculturais dos dois países das escolas investigadas, podemos dizer que na França, de um modo geral, existe uma ênfase em alguns aspectos formais da escolarização, desde a educação infantil. As atividades de linguagem da turma participante da pesquisa eram diversificadas e, em muitas situações, lúdicas e, com isso, as questões da infância eram consideradas. Aspectos da cultura escolar daquele país, no entanto, estavam presentes desde a Educação Infantil, como a disciplina e a atenção ao desenvolvimento psicomotor, com ênfase na escrita cursiva. O papel da escola, portanto, era o de, entre outras coisas, ensinar e possibilitar que os alunos, em sua maioria imigrantes ou filhos de imigrantes (tratavase de uma escola de ZEP), compreendessem aspectos diferenciados da cultura francesa, incluindo a escolar. Já no Brasil, o processo de escolarização a partir da Educação Infantil é bastante recente e não se caracteriza de maneira uniforme. Ainda se tem muitas dúvidas sobre o que fazer com as crianças dessa etapa da Educação Básica. O cuidado, o brincar e o ensinar se dividem ou se misturam nos diferentes sistemas públicos e privados de ensino.

Com base na análise das práticas das professoras participantes da nossa pesquisa, pudemos constatar que as duas docentes, mesmo considerando os aspectos singulares de suas práticas, desenvolviam atividades variadas relacionadas à leitura e à escrita e organizavam suas rotinas de forma a explorar diferentes estratégias que contribuíam para que as crianças avançassem em seus conhecimentos acerca do sistema de escrita alfabética, respeitando a dinâmica de uma turma da Educação Infantil. As docentes organizavam o seu trabalho pedagógico de modo a privilegiar a leitura e exploração de textos que faziam parte do universo infantil, e o desenvolvimento de atividades reflexivas e diversificadas que possibilitavam a compreensão do sistema de escrita alfabética.

Se relacionarmos os dados desse estudo com os desenvolvidos por Aquino (2008) e Lima (2010), podemos concluir e ressaltar a importância da prática pedagógica de ensino da língua escrita no desenvolvimento dos alunos da Educação Infantil no que se refere à apropriação da escrita alfabética. No nosso estudo, apesar de os alunos pertencerem a países distintos (mas ambos com sistema de escrita de natureza alfabética), a maioria das crianças das duas turmas concluiu o ano letivo compreendendo alguns princípios do sistema de escrita alfabética, principalmente o de que a escrita nota a pauta sonora das palavras. Para isso, as crianças de ambas as turmas participaram, ao longo do ano, de atividades interessantes de leitura 
e de reflexão sobre a língua e não precisaram fazer, diariamente, as mesmas atividades de cópia e memorização de letras e sílabas, como o fizeram as crianças da rede privada da escola observada por Lima (2010), ou como ainda fazem muitas crianças que estudam em escolas das redes pública e privada do Brasil.

$\mathrm{O}$ documento da BNCC, na página 33, faz referência às Diretrizes Curriculares Nacionais para a Educação Infantil, em seu Art. $4^{\circ}$, ao definir a criança como

\footnotetext{
"sujeito histórico e de direitos que, nas interações, relações e práticas cotidianas que vivencia, constrói sua identidade pessoal e coletiva, brinca, imagina, fantasia, deseja, aprende, observa, experimenta, narra, questiona e constrói sentidos sobre a natureza e a sociedade, produzindo cultura." (BRASIL, 2009)
}

Se a criança deve ser vista como um sujeito histórico e de direitos que aprende nas interações e práticas cotidianas que vivencia, então cabe a nós, educadores, garantirmos que entre esses direitos esteja o de aprender a ler e escrever. Não defendemos que a criança se alfabetize na Educação Infantil, mas que ela aprenda a ler e a escrever por meio de diferentes atividades vivenciadas na escola e fora dela. Em relação à escola, que tais atividades sejam lúdicas, interessantes e desafiadoras de modo a garantir que avancem em seus conhecimentos sobre a escrita desde a Educação Infantil.

Nessa perspectiva, gostaríamos de destacar a necessidade de se discutir, nos cursos de formação (inicial e continuada) de professores, sobre como trabalhar os conhecimentos relativos ao domínio da escrita alfabética com crianças da Educação Infantil, uma vez que, com base na análise das práticas das docentes participantes desta pesquisa e de outras citadas nesse artigo, pode-se concluir que "brincando com a língua" e refletindo sobre ela, a criança constrói conhecimentos.

Enfim, diante das mudanças que ora nos são apresentadas e, sobretudo, diante da recente Política Nacional de Alfabetização (2019) que defende a implementação do método fônico de alfabetização, corremos o risco de vermos crescer, nas salas de aula das escolas públicas do nosso país, práticas de ensino da leitura e da escrita com ênfase no treino, memorização e repetição de correspondências entre fonemas e grafemas. E, como sabemos, tais práticas não costumam considerar as crianças como sujeitos criativos, inventivos e singulares, que estão sempre construindo novos conhecimentos sobre a escrita e, principalmente, sobre o mundo. 


\section{REFERÊNCIAS}

AQUINO, S. B. O trabalho com consciência fonológica na educação infantil e o processo de apropriação da escrita pelas crianças. In: Anais da $31^{\text {a }}$ Reunião anual da Associação Nacional de Pós-Graduação e Pesquisa em Educação, Caxambu-MG, 2008.

ANDRÉ, M. E. D. A. Estudo de Caso: seu potencial em educação. In: Cadernos de Pesquisa. Vol. 4 9, pp. 51-64, São Paulo, 1984

BRANDÃO, A. C. P. e LEAL, T. F. Alfabetizar e letrar na Educação Infantil: o que isso significa? In: BRANDÃO, A. C. P. e ROSA, E. Ler e Escrever na Educação Infantil: discutindo práticas pedagógicas. Belo Horizonte: Autêntica, 2011.

BRANDÃO, A. C. P. e SILVA, A. da. O ensino da leitura e escrita e o livro didático na Educação Infantil. Educação (Porto Alegre), v. 40, n. 3, p. 440-449, set-dez, 2017.

BRASIL. Ministério da Educação. Referencial curricular nacional para a Educação Infantil / Ministério da Educação e do Desporto, Secretaria de Educação Fundamental. Brasília: MEC/SEF, 1998.

BRASIL. Ministério da Educação. Ensino fundamental de nove anos: orientações para inclusão da criança de seis anos de idade / Ministério da Educação e do Desporto, Secretaria de Educação Fundamental. - Brasília: MEC/SEF, 2006

BRASIL. Ministério da Educação. Secretaria de Educação Básica. Diretrizes curriculares nacionais para a educação infantil / Secretaria de Educação Básica. - Brasília: MEC, SEB, 2010

BRASIL. Lei no 11.274, de 6 de fevereiro de 2006. Altera a redação dos art. 29, 30, 32 e 87 da lei n 9.394, de 20 de dezembro de 1996. Diário Oficial da União - seção 1 - 7/2/2006, página 1.

BRASIL. Lei no 13.005, de 25 de junho de 2014. Aprova o Plano Nacional de Educação - PNE e dá outras providências. Diário Oficial da União - Seção 1 - Edição Extra - 26/6/2014.

BRASIL. Ministério da Educação. Secretaria de Educação Básica. Base Nacional Comum Curricular. Secretaria de Educação Básica. - Brasília: MEC, SEB, 2017

BRASIL. Decreto n ${ }^{\circ}$ 9.765, de 11 de abril de 2019. Institui a Política Nacional de Alfabetização. Diário Oficial da União - Seção: 1 - Extra - Edição: 70-A - 11/04/2019 - Página: 15.

CHARTIER, A.-M. A leitura e sua aquisição: modelos de ensino, modelos de aprendizagem. In: CHARTIER, A.- M. Práticas de leitura e escrita: história e atualidade. Belo Horizonte: Ceale/Autêntica, 2007.

CHARTIER, A.-M. Ensinar a ler e escrever, entre teoria e prática. Palestra apresentada na V Semana da Educação, da Fundação Victor Civita. São Paulo, 20 de outubro de 2010.

CHARTIER, A.-M. Os três modelos da leitura entre os séculos XVI e XXI: como as práticas sociais transformam os métodos de ensino. Revista Brasileira de História da Educação, Maringá-PR, v. 16, n. 1 (40), p. 275-295, jan./abr. 2016. 
COUTINHO-MONNIER, M. de L. Práticas de alfabetização com uso de diferentes manuais didáticos: o que fazem professores no Brasil e na França? O que os alunos aprendem? Tese (doutorado em Educação), Universidade Federal de Pernambuco, 2009

FERREIRO, E.; TEBEROSKY, A. A psicogênese da língua escrita. Porto Alegre: Artes Médicas, 1984.

GOIGOUX, R.; CÈBE, S. e PAOUR, J.-L. Phono: pour développer les compétences phonologiques. Hatier : Paris, 2004.

LIMA, A. R. Educação Infantil e alfabetização: um olhar sobre diferentes práticas de ensino. Dissertação (Mestrado em Educação) - Programa de Pós-Graduação em Educação, Universidade Federal de Pernambuco, Recife, 2010.

MORAIS, A. G. A apropriação do sistema de notação alfabética e o desenvolvimento de habilidades de reflexão fonológica. Letras de Hoje, Porto Alegre, v. 39, n.3, p. 35-48, 2004.

MORAIS, A. G. Sistema de Escrita Alfabética. 1ª ed. São Paulo: Melhoramentos, 2012.

REPUBLIQUE FRANÇAISE. Programme d'enseignement de l'école maternelle. Bulletin officiel spécial n² 2 du 26 mars 2015.

REPUBLIQUE FRANÇAISE. Programmes d'enseignement du cycle des apprentissages fondamentaux (cycle 2), du cycle de consolidation (cycle 3) et du cycle des approfondissements (cycle 4). Bulletin officiel spécial n 11 du 26 novembre 2015.

SOARES, M. Letramento: um tema em três gêneros. Belo Horizonte: Autêntica, 1998

SOARES, M. Letramento e alfabetização: as muitas facetas. Revista Brasileira de Educação. No. 25, 2004, p. $5-17$

SOARES, M. Formação de rede: uma alternativa de desenvolvimento profissional de alfabetizadores/as. Cadernoscenpec. São Paulo, v. 4, n. 2, p. 146-173, dez 2014.

SOARES, M. Alfabetização: a questão dos métodos. São Paulo: Contexto, 2016.

\section{NOTAS}

1 Este artigo apresenta resultados de pesquisa desenvolvida com auxílio financeiro do CNPq.

2 Como publicado no Bulletin officiel spécial n² du 26 mars 2015, a Educação Infantil (École Maternelle) na França não é obrigatória.

3 Nos anos 1980, o governo francês identificou "zonas de educação prioritárias" (ZEPs) em áreas com populações desfavorecidas - muitas delas habitadas por imigrantes.

4 Os professores experientes podiam se candidatar à função de professor formador e participar das formações continuada do Institut universitaire de formation des maitres- IUFM, extinto em 2013 e absorvido pelas Écoles supérieures du professorat et de l'éducation -ESPE.

5 Na França, o ano letivo inicia em setembro e é finalizado no final de junho do ano seguinte. $\mathrm{Na}$ época da coleta dos dados da pesquisa, os alunos da Educação Infantil frequentavam a 
escola quatro dias por semana (na quarta não havia aula), nos seguintes horários: 08:30 às 11:30 e 13:30 às 16:30 (podiam almoçar na escola e permanecer nela até às 18 horas). Em geral, a cada seis semanas de aula os alunos vivenciavam duas semanas de férias. Assim, no período em que realizamos as observações houve quatro semanas de férias escolares.

Submetido: 03/02/2019

Aprovado: 11/06/2019

Contato:

Eliana Borges Correia de Albuquerque

Rua Dr. Genaro Guimarães, nº 90, apt. 2501|Casa Amarela

Recife | PE |Brasil

CEP 52.070-040 